Umantsiv Galyna,

$\mathrm{PhD}$ (Economics), associate Professor Kyiv National University of Trade and Economics

Kyiv, Ukraine

ORCID 0000-0002-5410-1363

ResearcherID O-4870-2016

Martyniv Iryna,

$\mathrm{PhD}$ (Economics)

Kyiv National University of Trade and Economics

Kyiv, Ukraine

ORCID 0000-0002-3811-683X

ResearcherID N-1909-2016

\title{
ORGANIZATIONAL AND INFORMATIONAL MODEL OF ANALYSIS OF COMMERCIALIZATION OF INTELLECTUAL PROPERTY OBJECTS
}

The organizational and informational model of the analysis of commercialization of intellectual property objects was developed and proposed. The system of indicators of commercialization of intellectual property objects is defined. The stepwise sequence of the analysis of commercialization of intellectual property objects is presented.

Keywords: intellectual property, innovation, commercialization of intellectual property objects, analysis of commercialization of intellectual property objects

Уманців Галина, Мартинів Ірина. Організаційно-інформаційна модель аналізу комерціалізації об'єктів інтелектуальної власності

Розроблено та запропоновано організаційно-інформащійну модель аналізу комериіалізації об'єктів інтелектуальної власності. Визначено систему показників комериіалізації об'єктів інтелектуальної власності. Наведено поетапну послідовність проведення аналізу комериіалізації об 'єктів інтелектуальної власності.

Ключові слова: інтелектуальна власність, інноваційна діяльність, комериіалізація об’єктів інтелектуальної власності, аналіз комериіалізаиії об'єктів інтелектуальної власності

Formulation of the problem. The rapid trends in the development of the world economy embody the Fourth Industrial Revolution («Industry 4.0»), whose task is to use information technology in production to preserve and enhance the country's competitive advantage [6].The results of the introduction of Industry 4.0 through the combination of modern information and communication technologies with industrial 
production are cyber-physical systems, big data, artificial intelligence and 3D-printing. The development, creation and implementation of such innovative product groups is due to an effectively established process of commercialization of intellectual property objects, which is an orderly sequence of interrelated actions and operations to create (develop), use and transfer property rights to intellectual property objects for the purpose of obtaining economic benefits and social impact formation.

The activation of the process of commercialization of intellectual property objects is gaining momentum in Ukraine. According to research by the IT Ukraine Association and the Office of Effective Regulation (BRDO), Ukraine's information technology sector is the second largest service export industry, accounting for $20 \%$ of total services exports [5].

Since the commercialization of intellectual property is an independent process, the list of objects of its analysis, and, consequently, the groups of absolute and relative indicators of their analysis, is greatly expanded. In contrast to the costs of creating objects in material form, the costs of the enterprise in the process of creating intellectual property objects are characterized by increased risk. It is these particular features of the intellectual property creation process that cause some difficulty in using the evaluation results (i.e., determining the effectiveness and efficiency of the process). Together with the intensification of the process of commercialization of intellectual property objects in Ukraine, domestic companies are faced with the question of developing organizational and information support for the analysis of the efficiency of implementation of the process of commercialization of intellectual property objects, which will allow:

- evaluate the enterprise's ability to commercialize intellectual property objects from all factors;

- choose a commercialization strategy that will maximize incomes and generate maximum profits;

- determine the composition and dynamics of costs that arise from the moment the idea is generated before its use;

- get maximum efficiency with minimal risks;

- to calculate the reliable amounts of profits that the enterprise receives in the process of commercialization of intellectual property objects.

Analysis of recent researches and publications. In the modern scientific literature, the most frequently investigated issues are the analysis of innovative activity of the enterprise (O. Babchynska [1], O. Chereshniuk [3]), features of the formation of indicators of one way or form of commercialization of intellectual property objects (O. Klipkova [7], Yu. Kovtunenko [9], R. Kostsyk [8], D. Tymofieiev [11], S. Filyppova [4]).Given the significant contribution of scientists and taking into account current trends in the development of Industry 4.0, there is a need to develop organizational and information support for the analysis of commercialization of intellectual property as a holistic process. 
Presenting main material. In the process of analyzing the commercialization of intellectual property objects, as well as any other type of activity of the enterprise, its information support becomes important. Getting timely, accurate, complete, and objective information from management is the key to making effective management decisions. That is why it is necessary to constantly transform economic information into analytical. According to G. Mitrofanov, organizational support for the analysis of the activity of the enterprise is based on the theoretical and methodological foundations of its conduct, which include the purpose, content, tasks, objects, subjects, system of economic indicators, methodical methods of processing of input information and generalization of the analysis results [10].Clarification of theoretical and methodological aspects of the analysis of the process of commercialization of intellectual property objects has allowed to develop the organizational and informational model of the enterprise in the part of commercialization of intellectual property objects (table 1).

Table 1

\section{Organizational and informational model of analysis of commercialization of intellectual property objects}

\begin{tabular}{|c|c|c|}
\hline \multicolumn{3}{|c|}{ 1. The purpose, content and tasks of the analysis of commercialization of intellectual } \\
property
\end{tabular}


2. The objects and subjects of commercialization of intellectual property objects

\begin{tabular}{|c|c|}
\hline 2.1. Objects & 2.2. Subjects \\
\hline $\begin{array}{l}\text { Licensing agreements, franchise agreements, } \\
\text { franchises, royalties (in the form of income or } \\
\text { expenses), factors affecting the choice of the IPO } \\
\text { commercialization strategy, capital, current and } \\
\text { future expenses, income and future periods, } \\
\text { financial results, tax implications }\end{array}$ & $\begin{array}{l}\text { Company management, financial and economic } \\
\text { department, control and audit department, law } \\
\text { department, department of innovative } \\
\text { development, state, investors, creditors, civil } \\
\text { society, competitors }\end{array}$ \\
\hline \multicolumn{2}{|c|}{ 3. The system of economic indicators of analysis of commercialization of IPO } \\
\hline 3.1. Absolute cost metrics & $\begin{array}{l}\text { 3.2. Relative indicators obtained from } \\
\text { analytical procedures with accounting data }\end{array}$ \\
\hline $\begin{array}{l}\checkmark \text { The value of IPO in the composition of IA, the } \\
\text { magnitude of obligations to use the rights to } \\
\text { intellectual property objects granted to the } \\
\text { enterprise, indicators of the dynamics of } \\
\text { intellectual property objects in the composition } \\
\text { of intangible assets, income and expenses / } \\
\text { income associated with the process of } \\
\text { intellectualization objects property }\end{array}$ & $\begin{array}{l}\checkmark \text { Specific indicators of the structure of the } \\
\text { IPO in the composition of IA, income and } \\
\text { expenses associated with the process of } \\
\text { commercialization of intellectual property, } \\
\text { specific indicators of the dynamics of the } \\
\text { IPO in the composition of IA, income and } \\
\text { expenses associated with the process of } \\
\text { commercialization of IPO, general and } \\
\text { specific indicators of the effectiveness of } \\
\text { thecommercialization of IPO }\end{array}$ \\
\hline \multicolumn{2}{|c|}{ 4. The informational support of analysis of commercialization of IPO } \\
\hline 4.1. External infor & 4.2. Internal information \\
\hline Regulatory and reference & Accounting, planned \\
\hline \multicolumn{2}{|c|}{ 5. Methods of processing primary (input) information } \\
\hline 5.1. Economic and logical methods & 5.2. Economic and mathematical methods \\
\hline Generalization and imnlementation & sults of the WIP commercialization analysi \\
\hline
\end{tabular}

Source: developed by the authors

At each stage of the commercialization of intellectual property objects (initiation, acquisition (creation) of intellectual property objects, marketing of intellectual property objects, use of intellectual property objects) management has different information needs, including the definition of indicators for different objects of commercialization analysis. At the initiation stage, for example, the main object of analysis is the current costs of the enterprise for the investment project, the likely benefits, payback, profitability from it, as well as assessing the impact of factors on the choice of commercialization strategy. At the stage of acquisition (creation) of intellectual property objects, in addition to the expenses of the entrepreneur, which form the initial value of intangible assets, indicators of the structure and dynamics of intangible assets in the assets of the enterprise, indicators of the efficiency of their use, etc. At the stage of marketing ofintellectual property objects, the object of analysis is also the costs, but related to theinnovative products promotion. At the stage of the use of intellectual property objects, the composition of the objects of commercialization analysis is significantly expanding, in particular indicators of not only the expenses, 
but also the profit received by the enterprise from commercialization, as well as its financial result. Given that the analysis of commercialization of intellectual property objects involves the calculation of a large number of indicators, it is proposed to organize them according to the stages of commercialization (table 2).

Table 2

\section{The system of indicators of analysis of commercialization of intellectual property objects}

\begin{tabular}{|c|c|c|c|}
\hline $\begin{array}{c}\text { The stage of } \\
\text { commercialization }\end{array}$ & The object of analysis & The absolute figure & The relative indicator \\
\hline Initiation & $\begin{array}{l}\text { current costs of the enterprise } \\
\text { on the innovation-investment } \\
\text { project, probable benefits, } \\
\text { profitability, profitability, } \\
\text { assessment of the influence } \\
\text { of factors on the choice of } \\
\text { commercialization strategy }\end{array}$ & $\begin{array}{l}\text { R\&D expenditures, } \\
\text { net present value, } \\
\text { reported costs, etc. }\end{array}$ & $\begin{array}{l}\text { return on investment, } \\
\text { payback period, production } \\
\text { optimization indices, etc. }\end{array}$ \\
\hline $\begin{array}{c}\text { Acquisition (creation) } \\
\text { of IPO }\end{array}$ & $\begin{array}{l}\text { capital and recurrent costs } \\
\text { associated with the } \\
\text { acquisition (creation) of IPO } \\
\text { as part of the intangible } \\
\text { assets }\end{array}$ & $\begin{array}{l}\text { the amount of capital } \\
\text { and operating costs } \\
\text { associated with the } \\
\text { acquisition (creation) } \\
\text { of IPO as a part of the } \\
\text { IA, the indicators of } \\
\text { IPO dynamics in the } \\
\text { composition of } \\
\text { intangible assets, } \\
\text { income, and expenses } \\
\text { / revenues related to } \\
\text { the process of } \\
\text { commercialization of } \\
\text { intellectual property } \\
\text { objects }\end{array}$ & $\begin{array}{l}\text { specific indicators of the } \\
\text { structure and dynamics of } \\
\text { the IPO as part of the } \\
\text { intangible assets }\end{array}$ \\
\hline Marketing of IPO & $\begin{array}{l}\text { costs of marketing IPO, } \\
\text { including marketing costs }\end{array}$ & $\begin{array}{l}\text { the amount of } \\
\text { marketing and } \\
\text { marketing costs }\end{array}$ & $\begin{array}{l}\text { specific indicators of the } \\
\text { structure and dynamics of } \\
\text { marketing and marketing } \\
\text { costs }\end{array}$ \\
\hline Use of IPO & $\begin{array}{l}\text { capital, recurrent and future } \\
\text { expenses related to the } \\
\text { commercialization of the } \\
\text { IPO, income of the reporting } \\
\text { and future periods and the } \\
\text { financial result from the } \\
\text { commercialization of } \\
\text { theIPO, tax consequences; } \\
\text { royalties (in the form of } \\
\text { income or expenses) and the } \\
\text { like }\end{array}$ & $\begin{array}{l}\text { the amount of capital, } \\
\text { current and future } \\
\text { expenses, income of } \\
\text { the reporting and } \\
\text { future periods }\end{array}$ & $\begin{array}{l}\text { specific indicators of the } \\
\text { structure and dynamics of } \\
\text { the income and expenses } \\
\text { associated with the process } \\
\text { of commercialization of the } \\
\text { IPO, indicators of efficiency } \\
\text { of use of the intangible } \\
\text { assets, indicators of the } \\
\text { efficiency of } \\
\text { commercialization of the } \\
\text { IPO }\end{array}$ \\
\hline
\end{tabular}

Source:developed by the authors. 
The proposed indicators make it possible to analyze and evaluate the process of commercialization of intellectual property as an independent holistic process. Based on the principle of complexity of economic analysis, according to which a comprehensive study of causal interdependencies, a comprehensive assessment of the input parameters of the functionalstructure, their change and development at the object under study in space and time, quantitative and qualitative features and output (effective) parameters of this process [2],analysis of the commercialization of intellectual property objects should ensure that the financial condition of the firm corresponds to its targets for innovative development;assessing the capacity for innovative development [1]; choice of commercialization strategy; evaluation of intellectual property utilization indicators; assessment the impact of intellectual property transactions on the firm's financial performance. That is why it is proposed to analyze the commercialization of intellectual property in such a sequence (figure 1).

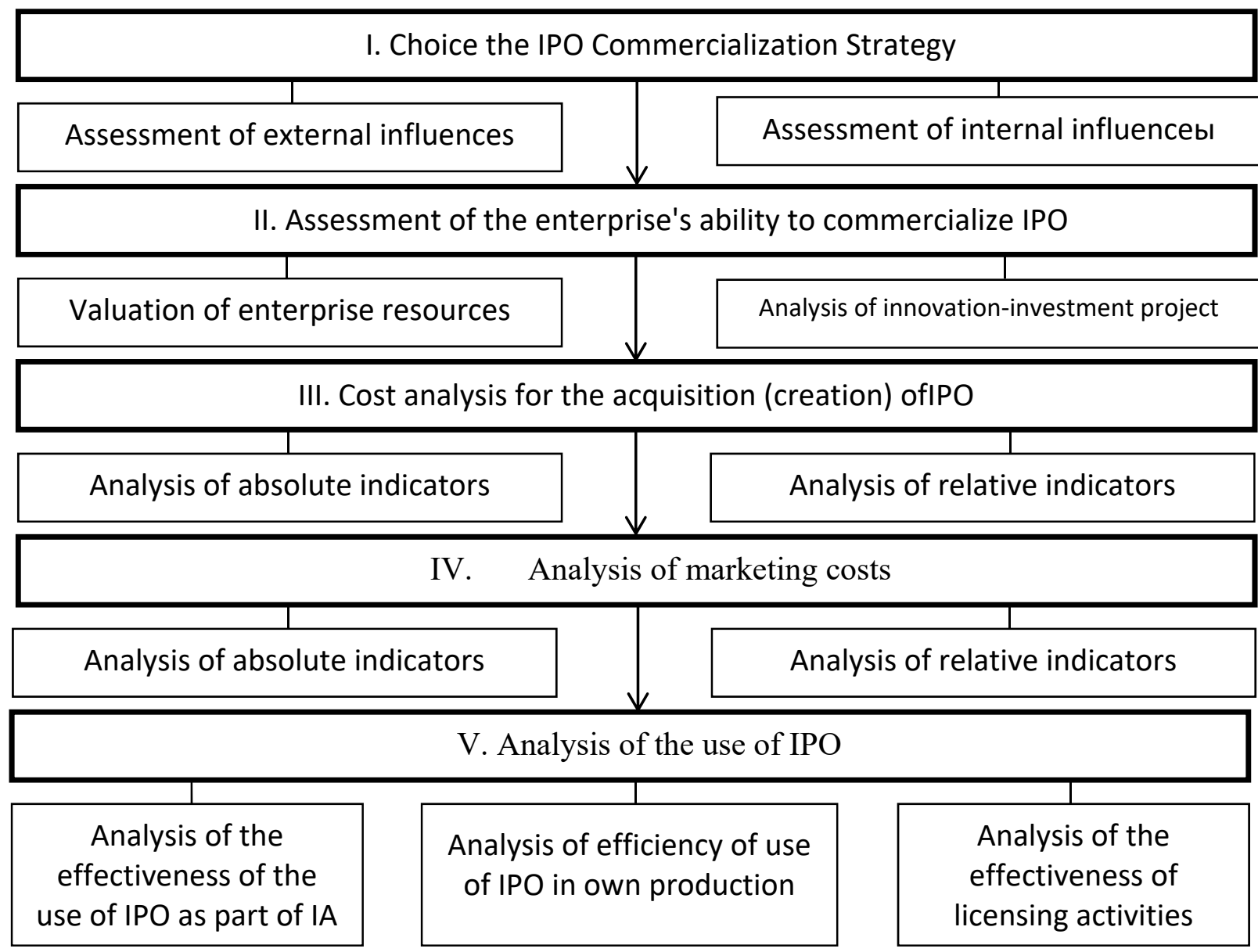

Figure 1.Stages of analysis of commercialization of intellectual property objects

Source: developed by the authors.

The proposed stages of the analysis of commercialization of intellectual property objects make it possible to analyze commercialization as a holistic process. 
Conclusion. Organizational and informational support plays a key role in the analysis of the commercialization of intellectual property.. The need to develop organizational support for the process of commercialization of intellectual property objects in terms of identifying the purpose, content, tasks, objects, entities, system of economic indicators, which is presented in the form of organizational and informational model, as a component of improving the quality of the project management system. This made it possible to form an organizational and information model for the analysis of the commercialization of intellectual property objects, which is the basis for the development of a methodological toolkit for the analysis of indicators of risk diagnostics and assessment of factors influencing the effectiveness of commercialization of intellectual property objects. In order to meet the information needs of users regarding the commercialization of intellectual property, a system of indicators for the commercialization of intellectual property at each of its stages was developed. These proposals led to the development of stages of analysis of commercialization of intellectual property objects as a holistic process.

\section{REFERENCES}

1. Babchynska, O. I. (2014). Features of evaluation of efficiency of innovative activity of the enterprise [Osoblyvosti ocinky efektyvnosti innovacijnoyi diyal'nosti pidpryyemstva]. Visnyk Hmel'nycz'kogo nacional'nogo universytetu. Ekonomichni nauky, 4(1), 87-92. Retrieved from https://news.finance.ua/ru/news/-/437600/it-sferastala-vtoroj-v-ukraine-po-eksportu-uslug [in Ukrainian]

2. Butko, A. (2012). In The theory of economic analysis. Kyiv: Kyiv National University of Trade and Economics. $411 \mathrm{p}$.

3. Chereshniuk, O. (2015). Accounting and analysis of innovation activity in the sugar industry [Oblik ta analiz innovacijnoyi diyal'nosti na pidpryemstvah czukrovoyi promyslovosti] (dissertation). Ternopil National Economic University, Ternopil. 251 p. [in Ukrainian]

4. Filyppova, S., \& Kovtunenko, Y. (2013). Features of the process of commercialization of innovative developments of an industrial enterprise [Osoblyvosti procesu komercializaciyi innovacijnyh rozrobok promyslovogo pidpryemstva]. Lugansk: Knowledge. 214 p.

5. Finance.UA. (2018, October 30). IT-sphere became the second in Ukraine in export of services [IT-sfera stala vtoroj v Ukrayne po eksportu uslug]. Retrieved from https://news.finance.ua/ua/news/-/437600/it-sfera-stala-drugoyu-v-ukrayini-zeksportu-poslug [in Ukrainian]

6. Industry 4.0 [Industriya 4.0]. Retrieved from http://www.it.ua/knowledgebase/technology-innovation/industry-4 [in Ukrainian] 
7. Klipkova, O. I. (2017). Commercialization of intellectual property in the system of innovative development of enterprises [Komercializaciya ob'yektiv intelektual'noyi vlasnosti v systemi innovacijnogo rozvytku pidpryemstv] (dissertation). Lviv University of Trade and Economics, Lviv. 272 p. [in Ukrainian]

8. Kostsyk, R. (2016). Commercialization of innovative products of machinebuilding enterprises [Komercializaciya innovacijnoyi produkciyi mashynobudivnyh pidpryemstv] (dissertation). Lviv Polytechnic National University, Lviv. 238 p.

9. Kovtunenko, Y., \& Bashynska, I. (2012). Documentary analysis software gradual process of commercialization of university research activity [Dokumental ne zabezpechennya poetapnogo analizu procesu komercializaciyi naukovo-doslidnoyi diyal'nosti Vnz]. Donetsk: Knowledge. 181 p.

10. Mitrofanov, G., Kravchenko, G., \& Barabash, N. (2002). Financial analysis. Kyiv: Kyiv National University of Trade and Economics. 301 p.

11. Tymofieiev, D., \& Borysiuk, O. (2017). Techno-economic factors influencing the efficiency of commercialization of innovations [Texniko-ekonomichni chynnyky vplyvu na efektyvnist' komercializaciyi innovacij]. Naukovyj Visnyk Mizhnarodnogo Gumanitarnogo Universytetu : Zbirnyk naukovyh prac'. Serija: Ekonomika i Menedzhment, (23), 136-139 [in Ukrainian] 